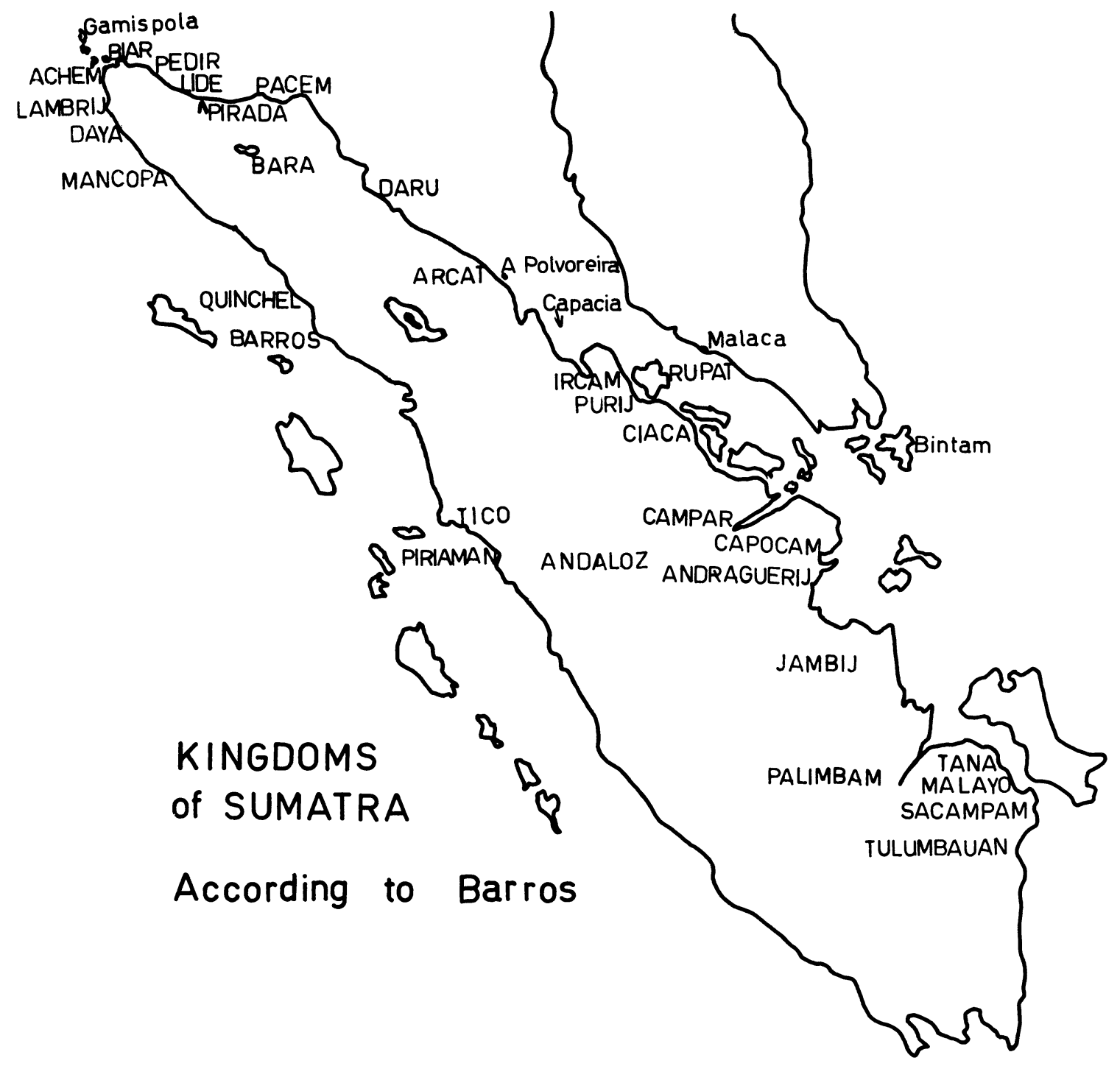




\section{SUMATRA THROUGH PORTUGUESE EYES: EXCERPTS FROM JOÃO DE BARROS' DECADAS DA ASIA}

Mark Dion

Soon after the Portuguese arrived in Indonesia, some four hundred years ago, they undertook a major literary effort to describe its lands and peoples, partly as an inventory of their nascent empire, but mainly as a celebration of their feats of discovery. The sixteenth century became a golden age of Portuguese historical writing when the attention of the court and the literati was focused on the expansion to the East and when a whole series of reports, chronicles, travelogues and tales of national adventure became available to the reading public.'

Despite the evident bias of the writers in favor of things Portuguese, and their occasional uncritical repetition of the stories and legends they had heard, the bulk of the material which they produced is still of considerable interest, not only as literature but also as a source of information on the early history of the archipelago. Other European travellers had previously passed that way, notably Marco Polo on his return from China in the late thirteenth century, but the Portuguese were the first to attempt a systematic description of the region as they found it--before the indigenous society had been deeply affected by Western influence, including their own.

Sumatra, the first island of the archipelago to be reached by the Portuguese, was described in considerable detail by several of these early authors. One of the most famous, Tome Pires, was sent to Goa in 1511 as a Factor, or supervisor, of the drug trade between the Orient and Lisbon; he travelled widely throughout Asia and proved a keen observer of social customs as well as commercial opportunities. His major objective in writing the Suma oriental, however, was to convince the King of the worth of the newest Portuguese possession, Malacca, and he tended to treat lightly the many obstacles to Portuguese settlement and control of the area. ${ }^{2}$ Pires' account of the early history and traditions of Sumatra was based mainly on personal experience and it lacked the archival documentation that was available to

1. In fact, because it wished to keep the profitable spice route a secret from the rest of Europe, the Portuguese Crown prohibited the publication of the earliest writings for almost forty years.

2. Tomé Pires' work was written in Malacca and Goa between 1512 and 1515. Lost for centuries, the manuscript was discovered in Paris in 1937 and has been translated into English by Armando Cortesão. The Suma Oriental of Tome Pires (London: Hakluyt Society, 1944), 2 Volumes. 
João de Barros, the official historian of the Portuguese Court. Barros, though he never went farther east than the coast of present-day Ghana, "probably saw more documents on his subject than any man before or since," according to the late I.A. MacGregor, a British historian of sixteenth-century Malaya. ${ }^{3}$

Barros worked as Treasurer and later Factor of the Casa da India, the Lisbon headquarters for all Portuguese commercial and colonial activities in Asia and Africa; in his spare time, he complied a chronicle which he modeled on Livy's history of Rome entitled Decadas da Asia: Dos Feitos que os Portuguezes Fizeram no Descubrimento das Terras e Mares do Oriente [Decadas da Asia: Deeds Done by the Portuguese in their Discovery and Conquest of the Seas and Lands of the East]. ${ }^{4}$ His work was based on the Lisbon archives, interviews with returned Portuguese travellers and translations of Persian, Arabic and Indian manuscripts. Although he began writing in 1539, the first volume was not published until 1552; Decada II appeared in 1553; Decada III in 1563; Barros' last volume, Decada IV, did not appear until after his death and was edited by his colleague, the Royal Geographer. In the meantime, however, nine succeeding Decadas had already been published by Barros' successor in the post of Court Historian, Diogo do Couto, who spent most of his life in India as superintendent

of the Royal Archives at Goa.

Barros' description of Sumatra was the fullest to appear since Marco Polo's Travels, and was unsurpassed until the publication of Valentyn's oud en Nieuw oost Indien in 1724. Some 300 years after Barros' work appeared, Crawfurd still found it worthy of extensive quotation in his Descriptive Dictionary of the Indian Islands and Adjacent Countries; he remarked, moreover, that "for the time in which he lived, Barros certainly made a faithful and judicious use of his opportunities." 5

3. I. A. MacGregor, "Some Aspects of Portuguese Historical Writing," in, D.G.E. Hall (ed.), Historians of Southeast Asia (London: Oxford University Press, 1961), p. 179.

4. Three editions of Barros' Decadas da Asia were consulted for this article; the original edition, published between 1552 and 1615 by the printer Bermão Balharde; the edition edited by Pagliarini, published in Lisbon by A Regia Officina Typografica between 1777 and 1788; and an edition edited by Hernani Cidade and Manuel Múrias, published in Lisbon by Divisão de Publicações e Biblioteca, Agência Geral das Colónias in 1945. The translations which follow have been made from the original edition because, according to Professor Boxer, the later editions are textually inaccurate and contain many misprints. Letter from $C$. R. Boxer, July $19,1969$.

5. John Crawfurd, A Descriptive Dictionary of the Indian Islands and Adjacent Countries (London: Bradbury \& Evans, 1856), P. 40. 
Cortesão, the translator of Pires, has suggested that Barros made extensive use of the Suma oriental in writing his own description of Sumatra, and he points specifically to the similarity in the list of kingdoms cited by both authors. Although Barros may well have had access to Pires' Suma Oriental, his own stillmissing Geography may have contained much of the physical and historical detail lacking in the Decadas. The Decadas seem to have relied on other official sources to which Pires probably did not have access.

Barros was an official historian par exceltence in that he sought not only to describe but also to justify. One is not surprised, therefore, that he paid less attention to describing Sumatra than did Pires, but instead preferred to concentrate on Portugiese deeds and strategies. In Boxer's words, Barros was a "wholehearted 'imperialist' in the nineteenth-century sense of the term, [and] firmly believed that Portugal had a divine mission to spread its religion and its rule by forcible measures in certain circumstances." 6 For Barros, Portugal's expansion in Asia became yet another battle in the unending struggle against the infidel. He never doubted its moral justification.

Barros' Decadas have never been translated in their entirety. The portions relating to the founding of Maladca were translated into French by Gabriel Ferrand in 1918 and published in the Journal Asiatique. " Two summaries in English of Barros' general comments on a number of Southeast Asian countries have appeared: one a doctoral dissertation at the University of Chicago by Zoe Swecker and the other a three-volume history of European activities in Asia during the sixteenth century, written by Donald Lach. Both works are based on later editions of the Barros text and are intended more as commentaries than translations. Translations of Portuguese accounts of specific sixteenth-century events, such as battles, voyages, embassies and the like, were published in 1968 by Ronald Bishop Smith in a book entitled The First Age. ${ }^{8}$

6. C. R. Boxer, "Some Portuguese Sources for Indonesian Historiography," in Soedjatmoko, et. al., An Introduction to Indonesian Historiography (Ithaca: Cornell University Press, 1965), p. 219 .

7. Gabriel Ferrand, "Malaka, le Malayu et Melayur," Journal Asiatique, Series 1l, volume Il (1918), pp. 431-4 38 .

8. Zoe Swecker, "The Early Iberian Accounts of the Far East, 1550-1660," (Unpubl. Ph.D. thesis, University of Chicago, 1960); Donald F. Lach, Southeast Asia in the Eyes of Europe (Chicago: University of Chicago Press, 1965); Ronald Bishop Smith, The First Age: of the Portuguese Embassies, Navigations and Peregrinations to the Kingdoms and Islands of Southeast Asia (1509-1521), (Bethesda, Md. Decatur Press, 1968). 
Contemporary students of Asia may find much that is objectionable in Barros' smugness and ethnocentricity but, given the tasks which he set for himself, that is to chronicle the deeds of his countrymen, provide a saga for the Portuguese nation and offer examples of patriotic conduct, his part-time project proved a great success. Those portions of his story which follow are full of details, verbosity and self-congratulation, but Barros' account is probably never deliberately false and does contain some interesting glimpses of Sumatra early in the sixteenth century, when Portuguese ships first sailed into the straits of Malacca. His account begins with the voyage of Diogo Lopes de Sequiera, the Portuguese fidalgo who led the expedition of discovery to Sumatra and Malaya.

In 1508, the King of Portugal, Dom Manuel I, despatched one of his captains, Diogo Lopes de Sequiera, to Cochin in India. At the same time, he sent orders to the first Portuguese Viceroy, Francisco d'Almeida, to expand the size of the fleet at the captain's disposal and to facilitate his mission to open trade relations with Malacca, the major entrepot of the Malay archipelago and an important Islamic Sultanate. When Lopes de Sequiera arrived in Cochin, after a lengthy voyage, which included several battles in Mozambique and the first exploration of the Madagascar coast, he found that Almeida had been replaced as Viceroy by the ambitious Afonso de Albuquerque, although the power struggle between the two men had not ended. In contrast to Almeida's cautious policy of establishing only naval supremacy, Albuquerque's design for relations with the East called for Portuguese control of the seas by means of fortresses, built at strategic points at the mouth of the Red Sea, along the Malabar Coast and on the Straits of Malacca. Consequently, when Lopes de Sequiera finally sailed from Cochin with his augmented fleet, his original instructions had been amended by the new Viceroy in keeping with this more aggressive posture vis-à-vis the archipelago. According to the Malay Annals, Lopes de Sequiera deliberately abused the hospitality of the Sultan of Malacca by attempting to build a fortified trading post near the city; it seems clear that the special instructions which he received in India were to manufacture a casus belli, which Albuquerque could then exploit. ${ }^{9}$ The following excerpts from Barros' Decadas da Asia deal with Lopes de Sequiera's brief stopovers in Sumatra, en route to Malacca, the first recorded Portuguese visit to what is now Indonesia.

9. Antonio Baião, Hernani Cidade and Manuel Mưrias (eds.), Historia da Expansão Portuguesa no Mundo, Volume II: Expansäo atraves do Oriente (Lisboa: Editorial Ática, $1 \overline{93} 9$ ), PP. 110-115, 140; Cf. D. G. E. Hall, A History of Southeast Asia (New York: MacMillan, 1968), p. 240 . 
DECADAS DA ASIA

João de Barros

Decada II, Livro IV, Capitulos iii and iv

Concerning the voyage which Diogo Lopes de Sequiera made after departing this kingdom in 1508

$* * * * * *$

Following his departure from Cochij [Cochin] on the eighth of September [1509], Diogo Lopes called next at the port of Pedir [Pidië], capital city of the kingdom of that name and one of many kingdoms on the island of Samatra [Sumatra], some of which we will describe later. ${ }^{1}$ He found in this port [of Pedir] five juncos [junks], which are naos ${ }^{2}$ or heavy cargo ships, but

1. Antonio Baião suggests that, in fact, Diogo Lopes arrived in Pedir on September 8 , because he could not have left cochin on that date and still have arrived at Malacca by September 11. According to Baião, a misplaced comma in the original text is responsible for this error. Antonio Baião, "A Politica de D. Francisco da Almeida, de Afonso de Albuquerque e de D. João de Castro," in Antonio Baião, Hernani Cidade and Manuel Múrias (eds.), Historia da Expansão Portuguesa no Mundo, Volume II: Expansão atraves do Oriente (Lisboa: Editorial Ática, 1939), p. 139. Later, in 1518, Diogo Lopes de Sequiera became Viceroy of India and served until 1522, when he returned to Portugal. He died in 1530.

2. The complicated Portuguese nomenclature for ships will not be set out here in its entirety. Suffice it to say that the most important vessel of this period was the nao, the largest cargo carrier and, at the same time, the most heavily armed; the galeão was an intermediate type sharing some of the characteristics of the nao, which was square-rigged, and some of the characteristics of the smaller caravela, which had lateen, or Arabic, rigging. Navios were large ships in general, both cargo carriers and fighting ships, while bateis were small warships. Of the other boats mentioned in the text: a fusta was equivalent to a pinnace, a batel was a small lateenrigged service craft similar to a cutter and a taforea resembled a nao except that dimensions below decks had been adjusted to permit passageway for horses. For a more complete description of Portuguese ships during this era, see: Quirino da Fonseca, "A Arquitectura Naval no Tempo dos Descobrimentos," in Baião, Historia da Expansão, Vol. II, PP. 39-46. 
because they flew the flags of Bengalla and Pegu, ${ }^{3}$ two kingdoms with which Portugal is at peace, they were not attacked. Upon learning of the arrival of the [Portuguese], the King [of Pedir] sent refreshments aboard but excused himself for not coming personally because he was indisposed; yet his words showed that he was pleased to receive news about the King of Portugal, with whom he desired peace and friendship. Diogo Lopes, to show his appreciation, promised to set up a padrão, such as the Portuguese are accustomed to use for such discoveries. ${ }^{4}$ And later when he was received in the same manner in Pacem [Pasai], some twenty leagues further along the coast of the island, another padrão was erected there, signifying that both these kings were held in friendship [by Portugal].

The King of Pedir offered [Diogo Lopes] a cargo of pepper, of which great quantities were harvested there and shipped to many places, but he did not accept because [loading] it would cause a delay. Diogo Lopes feared that during the onward voyage his fleet would be sighted by other junks, like those in the harbor, which come to load the merchandise available there, and that news [of his coming] might be carried to Malaca. Both these ports, Pedir and Pacem, are much frequented by trading ships, as is the case with all the kingdoms of Sumatra. Diogo Lopes was in a great hurry because he wanted to be the first to inform Malaca of his coming; yet, when he arrived, Malaca was already expecting him.

$* * * * * *$

[In the following chapters, Barros describes the city of Malacca, the history of its reigning house, the reception accorded Diogo Lopes de Sequiera, and, finally, the Sultan's "treacherous attack" which resulted in the imprisonment of Ruy de Araujo, the newly-appointed Factor, and a number of other members of Diogo Lopes' expedition. In 1511, Afonso de Albuquerque sailed from Cochin to overthrow the Sultan of Malacca and seize control of the Straits.]

Decada II, Livro VI, Capitulo ii

Concerning the passage of Afonso

de Albuquerque from Cochij to

the island Samatra where he was

3. Bengalla (Bengal) was an Indian kingdom on the delta of the Ganges River, and Pegu was a Mon kingdom in Lower Burma.

4. A padrão was a marble marker, about fifteen feet high, bearing the coat-of-arms of the Portuguese Crown; these were set up in many parts of Asia and Africa as symbols of discovery and possession. 


\author{
visited by the Kings of Pedir \\ and Pacem; and of the other \\ things he did before \\ arriving at Malaca.
}

$* * * * * *$

When Afonso de Albuquerque had departed Cochij, his whole fleet had sailed as a unit, but upon reaching the large gulf which lies between the island of Ceilão [Ceylon] and the place known as Gamispola, ${ }^{5}$ a great storm arose, and the sea swallowed up a galley commanded by Simão Martins. Thanks to God's intercessior, however, the whole company was rescued and taken aboard the nao which Fernão Peres commanded. Offsetting the loss, in the course of this passage, five ships of the Guzerates [Gujeratis] were captured while sailing between Malaca and Samatra.

The first port on the island of Samatra at which the Portuguese called was the city named Pedir, capital of the kingdom of the same name and one of the many kingdoms of this great island, some of which we will discuss later. Because the city lay some distance inland along a small river that was not navigable by large ships, Afonso de Albuquerque was met by an oardriven launch, carrying six Moorish notables ${ }^{6}$ and one Portuguese, who had been sent by the King of Pedir to offer whatever provisions were needed for the fleet's onward voyage, since the king understood its destination to be Malaca. Afonso de Albuquerque recognized the Portuguese [sailor] in the launch as one João Viegas, who had been with the expedition of Diogo Lopes de Sequeira and had been among the twenty-four men imprisoned in Malaca. ${ }^{7}$ Along with eight others, he had seized a launch and escaped to Samatra. Their flight from Malaca was arranged by a daughter of the lord in whose power they found

5. Gamispola was the name given by the Portuguese to the cluster of small islands just north of Atjeh. Marsden suggests that the name comes from Pulau Gomez, but this seems unlikely. William Marsden, The History of Sumatra (Kuala Lumpur: Oxford University Press, 1966), p. 412.

6. The phrase in Portuguese is honrados da terra, literally, "honored men of the land."

7. This incident is described in considerable detail by Castanheda in the chapter of his first volume dealing with Lopes de Sequiera's mission to Malacca. Fernão Lopes de Castanheda, Historia do Descobrimento e Conquista da India pelos Portugueses (Coimbra: Imprensa da Universidade de Coimbra, 1924). 
themselves. ${ }^{8}$ But as their launch approached the harbor of Pacem, another kingdom of the island [of Sumatra], a number of launches came out from the shore carrying Moors ${ }^{9}$ from Pacem. A battle ensued in which several Portuguese were badly wounded, among them João Dias, a servant of Diogo Lopes de Sequeira. The survivors fled to the port of Pedir where they were well received by the king, who gave orders that their wounds be treated; his generous offers of help and shelter, or so the Portuguese [survivors] said, was motivated by his knowledge that when the Captain Major of India [Albuquerque] learned what had happened to Diogo Lopes in Malaca, he would not delay in seeking revenge for these acts of treachery.

After questioning him closely about these matters, Afonso de Albuquerque ordered João Viegas to respond to the King of Pedir, thanking him for his offer of provisions and for the hospitality which he had shown João Viegas and the other Portuguese. In the two days that he remained there, Afonso de Albuquerque was visited by the king with small gifts and the peace treaty which Diogo Lopes had negotiated with [the king] was reaffirmed. Afonso de Albuquerque learned from João Viegas that a Moorish nobleman from Malaca, known as Nehoda Beguea, 10 was then in Pedir, and that this man had been one of the principal figures in the plot to arrest Diogo Lopes. Afonso de Albuquerque asked the King of Pedir to hand this man over to the Portuguese and the king promised to do so; at the same time, however, the king gave Nehoda Beguea a ship and sent him with a message to the King of Malaca, telling him of [Pedir's] experiences with Afonso de Albuquerque. The message was given to Nehoda Beguea more out of friendship toward him than out of regard for the King of Malaca. In his letter [to the King of Malacca], the King of Pedir asked that an infamy [in which Nehoda Beguea was implicated] be forgiven and pointed out that it was not the time for [Malacca] to have bad relations with its vassals, thus reminding

8. Their jailor in Malacca, one of the Sultan's principal lieutenants, had a daughter who helped the Portuguese prisoners escape from the city. See, Castanheda, Historia do Descobrimento, Vol. I, pp. $460 \mathrm{ff}$.

9. Moros, or Moors, were seen everywhere as the enemy and as identical to the Arab occupiers whom the Portuguese had fought for centuries in the Iberian Peninsula. Gentios, or heathens, were viewed as less hostile and as potential converts to Christianity. I. A. MacGregor, "Some Aspects of Portuguese Historical Writing," in D.G.E. Hall (ed.), Historians of Southeast Asia (London: Oxford University Press, 1961), pp. 174-175.

10. Nachoda is a Parsi title for ship's captain, usually used by Arab mariners. Sutan Mohammad Zain, Kamus Moderen Bahasa Indonesia (Djakarta: Penerbit Grafica, n.d.), p. 508 . 
him that Nehoda Beguea was an important man. This scandal concerned a recent incident in Malaca in which the king had uncovered a plot against his life by the Governor Bendahara, whom he had accused of treason and ordered killed; because Nehoda was himself under suspicion, he had fled from the fury of the king and sought refuge in Pedir, whose ruler was his great friend. Afonso de Albuquerque, realizing that the king did not mean to hand over Nehoda and that [the king] was as adept as all Moors at dissimulation with words, resolved not to await any more messages from the king, having also lost faith in his promise to pay 25,000 cruzados in exchange for the five ships which [the Portuguese] had captured from the Guzerates. Consequently, Afonso de Albuquerque sailed away from Pedir and went next to Pacem. There he was visited by the king, who asked forgiveness for the guilt he shared in the injuries inflicted on the members of João Viegas' party and for the death of one Portuguese. Because he did not wish to detain himself to avenge these affronts, Afonso de Albuquerque accepted the king's explanations calmly but resolved to return from Malaca by way of these ports to punish their sins. He was bade farewell by the King of Pacem, who in fact wanted very much for him to stay and promised him several days of celebration and entertainment, for a reason which we will soon see.

Now according to the Moorish pilots who had been brought aboard, the ships were beginning to enter the shallows [near Capacia in the Straits of Malacca]. Afonso de Albuquerque sent all the smaller vessels ahead, some following the coastline closely and others ranging farther out to sea, to act as a protective shield for the heavier war ships. While the ships were travelling in this formation, Aires Pereira de Berredo, captain of a small ship, came upon a native pangajoall passing stealthily along the coast out of fear for the Portuguese ships. Aboard the pangajoa was Nehoda Beguea; he not only defended his craft against the [Portuguese] boarding party but, because he was an homem de pessoa Lbrave man], he himself boarded the ship of Aires Pereira with drawn sword and wrought such havoc that no one remained aboard the vessel who was not covered with blood. Nehoda fought on until, more exhausted than defeated, he collapsed and fell to the deck. There seemed no recourse but for him to die from the multitude of wounds he had sustained, but no blood was seen to flow from them. Some of the sailors, noting that he was very expensively dressed, began to strip off his garments, but they were soon surprised to find a small bone bracelet around one of his arms, the upper portion mounted in gold, and the lower, of bone, against the flesh of his arm.

11. The term, pangajoa, or pangajava, for an ancient Malay warcraft powered by oars and sails, derives from the Malay word penjajap. Sebastião Rodolfo Dalgado, Glossario LusoAsiatico (Coimbra: Imprensa da Universidade de Coimbra, 1921), Vol. II, P. 158 . 
When they tried to remove it, blood poured forth from his wounds and he soon died. The Portuguese were terrified at this new thing they had learned about the Moors; the bone was from an animal in Jaua [Java] which they call Cabal, ${ }^{12}$ a thing much esteemed among the princes of the area because it is reputed to retain the blood in a man's body, exactly as they had seen. Aires Pereira, more pleased with the bracelet than with the victory itself, carried it to Afonso de Albuquerque, who prized it very much but later lost it, together with many other precious things on the return trip from Malaca aboard the ship Frol de $z a$ Mar, [which sank] as we shall recount.

It was this deed of Aires Pereira which Afonso de Albuquerque regarded as a sure sign that final victory awaited him in Malaca, because vengeance had now been exacted from the same Moor who was responsible ${ }^{3}$ for the crime against the Portuguese. He then realigned the ships in their previous sailing order and proceeded in this fashion until the Eve of St. John the Baptist, when they reached the island called A Polvoreira by the Portuguese and Barela by the Sumatrans, a place 40 leagues [160 miles] from Malaca. ${ }^{1}$

Near [the island] they caught sight of a junk, a ship of some 600 tons. Bateis were sent out from the naos of Dom João de Lima, Diniz Fernandes, Nuno Vaz de Castello-Branco and Afonso Pessoa. The junk paid little attention to their orders that it furl its sails, and when the bateis reached its side, the Portuguese called out that they wanted to come aboard. But the occupants of the deck above hurled down spears, one of which impaled Afonso Pessoa through the thigh, and forced the bateis away. Pero d'Alpoem was in the path of the junk when the other bateis pulled away and he tried to ram it [the junk], but the Moors were so industrious in raising their sails that he was left heading into the wind and was unable to give chase. It was still dark, although [now] close to dawn, and Afonso de Albuquerque maneuvered his great ship, the Frol de $z_{a}$ Mar, into the junk's path and rammed it, his artillery causing so much damage that 40 of the 300 men [aboard the junk] were killed. But these Moors, who are very expert at sea battles, set fire to their own junk, forcing Afonso de Albuquerque to break free and back away, because the flames reached so high that they licked at the caste 2 Ios da sua nao [the fortified towers of his nao]. Afonso de

12. Kabal is not an animal but rather the Malay word for invulnerable; amulets, or djimat, are often made from the bone or tusk of a particular animal, such as the tiger or elephant.

13. The phrase in Portuguese is o autor do damno, literally, "the author of the crime."

14. A Polvoreira is probably Pulau Berhala, located in the Straits of Malacca between Belawan and Lumut. 
Albuquerque escaped the danger because, knowing that the Moors in the region employed this trick, he had equipped his ship with oars and it quickly pulled away. As soon as they saw him escaping, the Moors tried to put out the fire which they had created by burning olio da terra [an oil from the earth], found in great quantities near Pedir, where it flows forth from a fountain. The Moors call this oil napta [naptha] ${ }^{15}$ and doctors consider it remarkable and an excellent [remedy] for some illnesses. We obtained some and found it very useful for treating coisas de frialdade e compressão dos nervios [Iow temperatures and nervous tension]. Finally, not to spend any more time with regard to this junk, it defended itself for two days but finally surrendered to the Portuguese, and was known thereafter among our men as 0 Bravo [the brave junk]. The men told Fernão Peres to ask the Captain [Albuquerque] to free [the crew of the junk] since they did not know against whom they were fighting and to receive them, not as enemies, but as vassals of the king of Portugual. It was in hopes of protection and patronage that they had surrendered and their faith should not be betrayed. Upon learning this, Afonso de Albuquerque spoke with the prisoners and offered to send them back to their own country.

One of them, a prince named Geinal, 16 told Afonso de Albuquerque that he was in fact the King of Pacem, whereas the man who called himself king and was in possession of the throne was a relative who had been governor under Geinal's father. When the latter had attained a great age, this governor had made himself the real ruler and Geinal, who was just a boy, was badly treated by him. When Geinal grew up and wanted to take charge of his own affairs, the tyrant had already made himself lord of the kingdom. Geinal fought two battles but was defeated and, seeing himself out of favor with his people and without forces to resist the tyrant, he went to Iaoa [Java], taking with him those princes of his lineage who were anxious to help in the restitution of his state.

Afonso de Albuquerque's fleet now resumed its voyage and, wasting no time, seized two junks. The first, a rich prize,

15. Marsden identifies napta as "liquid balsam," but maintains that the Portuguese erred in applying this term to the fountain at Pedir, which he believes produced minjak tanah, "earth oil" or kerosene. Marsden, History of Sumatra, P. 28. Dalgado's Glossario ( $\mathrm{p}$. 89) calls nafta a "bituminous liquid, volatile, inflammable, colorless, sharp-smelling and penetrating." As an example of its use, he cites this specific passage from Barros.

16. Geinal is variously rendered by Portuguese writers as Zinal, Sultan Zina and Sultan Zeinal. 
was taken by Dom João de Lima, ${ }^{17}$ Simão Miranda and Simão Afonso, when it happened across their path on way to Malaca. The other junk, proceeding from Malaca, was taken later by Nuno Vaz but, because it was night, the crew escaped in a bate $z$ and reached land. Because the most important cargo they were carrying was gold, they were able to save almost everything, but one passenger was found carrying money to Pacem. Afonso de Albuquerque learned from the other Moors who were seized aboard this ship that Ruy de Araujo [the first Factor at Malacca] and some of those who had been captured with him were still alive [and in Malacca]. He also learned about conditions in the city particularly about the great fear there of his fleet, whose sailing time was still unknown in Malaca. Having learned this from the Moors, and even then entering the territorial limits of Malaca, Afonso de Albuquerque wondered whether its king, filled with terror and aware that the Portuguese were coming, might not send out launches to intercept his ships in this region of shallows. He therefore began to regroup his whole fleet, aligning the ships in single file, some sailing in the wake of the others, and he proceeded in this way through the channel. But they did not encounter any of the great dangers which the Moors tell fables about finding in these low regions of Capacía, ${ }^{18}$ similar to those told about the channel of Frandes or the dangers of Scylla and Charybdis between Cezilia and Napoles [Sicily and Naples].

$* * * * * *$

[The remainder of this chapter concerns the arrival of Afonso de Albuquerque's fleet at Malacca and contains a description of the city and its harbor as they appeared in 1511. Barros returns to his narrative about Sumatra in Decada III, Livro V, Capitulo i with a passage describing the physical geography of the island. His account parallels, and may have relied upon, Tomé Pires' Suma Oriental, Book V, though Barros' treatment is considerably shorter and less detailed.]

\section{Decada III, Livro V, Capitulo i \\ A description of the island of \\ Samatra and its kingdoms and}

17. Dom João de Lima later became Governor of Calicut under the fifth Viceroy of India, Dom Henrique de Meneses. Grande Enciclopedia Portuguesa e Brasileira (Lisboa: Editorial Enciclopedia Limitada, n.d.).

18. The baixos, or shallows, of Capacía are located in the straits of Malacca between $2^{\circ}$ and $3^{\circ}$ north latitude. Ronald Bishop Smith, The First Age (Bethesda: Decatur Press, 1968), p. 9. 
of the things which happened there to the Portuguese and the reason why the Prince of the Kingdom of Pacem asked the Governor of India for help against a tyrant who had seized power in the kingdom.

In the beginning of Livro Six of Decada II, writing about the founding and early years of Malaca, we discussed the reason why ancient geographers erroneously called the island of Samatra the Chersoneso [Khersonese].19 The island is cast lengthwise across our navigational route [from India to Malacca] along a line running from northwest to southeast, taken from the southern quadrart, according to our navigation system, 20 and measures 220 leagues [880 miles] in length and 60 or 70 leagues [240 to

19. Barros referred to the ancient geographers' confusion in Decada II, Livro VI, Capitulo $i$, as follows: ". . . The city Afonso de Albuquerque had conquered was situated in a part of the world known to the geographers as Aurea Chersoneso. . . [ [He refers next to the location and history of Malacca, then continues.] Before we begin to discuss these things, however, we should discuss the use of the term Chersoneso, because some who read this history may not understand the language of the geographers; they should realize that this is a Greek word which was applied to a small point of land, a part of the earth attached to the whole by a narrow stem, like that of a leaf which attaches it to a branch; this shape can be seen in the Peloponeso, which we call Morea, and which in ancient times was the flower of Greece. Pliny compared it to the leaf of a plantain, which it does greatly resemble. This word, Chersoneso, though commonly applied to all formations of land that have this shape [i.e., peninsulas], was usually given an epicteto [epithet] by the geographers; thus we speak of things as golden, such as the Rio Lanais which divides Europe from Asia and which the geographers called the Taurica Chersoneso. This Chersoneso, where our city of Malaca stands, seems to have been given the epicteto of Aurea because of the great quantities of gold carried there from Monancabo and Barros, which are two comarcas [city-states] found on the Island of Samatra. Thus the real Aurea Chersoneso was not the Island of Samatra, as the ancients thought, but the terra firme [sic] where Malaca is now situated."

20. This means that if the southeast quadrant of the island were divided once more into four parts, it would incline more toward the south-southwest than simply due south. Hernani Cidade and Manuel Múrias (eds.), Decadas da Asia de João de Barros (Lisboa: Divisão de Publicações e Biblioteca, Agência Geral das Colónias, 1945), Decada III, p. 231, note. 
280 miles] in width at the widest point. This wide portion [of Sumatra] lies so close to Malaca across the narrowest point in the Strait that there is between them no more than 12 leagues [measured] almost to the boundary limits of the city of Malaca. And from this point east, as well as west, the mainland and the island are drawn apart from each other in such a way that the two entrances to the strait are wider than the middle. Along the entire length of the strait, however, there are shallows, salt marshes and small islands separated by channels in which ships can become lost. And for these reasons, as we have said before, it happened in ancient times that Ptolemy and the other geographers insisted that this strait was not navigable as [we know] it is today, because from sheer avidity men would normally have sought out all the passageways, but here it was dangerous to attempt to follow their design. The island is cut in two by the equator, which forms an $X$ with the easternmost coastline. The southernmost end of the island reaches six degree south latitude and lies very near the island of Java, thus forming a strait [the Sunda Strait] which even in ancient times was used by navigators of these oriental regions. At present, this area remains less populous and is full of islands and shallows. The northern end [of the island] reaches four degrees north latitude, ${ }^{21}$ is much clearer [less obstructed] along the coast and is much more heavily populated. In this region there is considerable naval traffic and the land itself produces many sorts of goods. All along the water's edge, swamps are generally found, [fed by] large rivers which come down from the mountainous wilderness, where a lake is situated from which some of the rivers proceed. ${ }^{2}$ The island lies along the equator and the humidity and high temperatures create extensive forests. The skies are very cloudy because although the sun burns from above, it is not able to penetrate or disperse the vapors, nor do the winds enter freely to blow away the miasma because the thick forests impede their entry. There is, therefore, much sickness, particularly among foreigners.

In addition to the great quantities of gold which are found in the island, there are also large deposits of tin, iron, copper, saltpeter, sulphur, tintas de minas [dyestuffs] and, in the Kingdom of Pacem, there exists a fountain which pours forth an oil called napta. In the middle of the island there is a mountain, something like the famous Etna on the island of Cezilia, which spouts flames; it is called Balaluam by the inhabitants. ${ }^{3}$ Among

21. In fact, the island of Sumatra lies in $6^{\circ}$ north latitude.

22. This probably refers either to Danau Toba in North Sumatra or to Laut Tawar in Atjeh.

23. None of the authors consulted had been able to identify this volcano. 
the numerous and diverse trees and plants which grow [in Sumatra] there are fruit trees, which the common people maintain, and others which nature itself has granted to ornament the island; and among the latter are the sendazo branco [white sandlewood], aguila [eaglewood or gharu wood], benjoim [gum benzoin] and trees like those found on the island of Burneo [Kalimantan] which yield camphor. Some say that the camphor from Samatra is finer, however, and of a different type than that which we find coming from China, because [the Chinese variety] is artificial, a composição [compound], while [the sumatran] is natural and of a distinct species. Among the spices are common pepper, long peppers, ginger, and cinnamon. Silk is made in such quantities that vast cargoes are sent to many parts of India. The wild animals and insects found in Samatra are of such variety that we lack names For them all, and even the natives of the island are unable to distinguish among them. The rivers are plentiful and teem with a variety of fish, while in some rivers, like the Siaca [Siak], shad are caught but the local people use only the eggs, of which there are a much greater quantity than is produced by European [shad].24 The basic diet of the people is mi tho [millet] and rice, but also includes many nuts and wild fruits from the forest. Due to the climate, they cannot [successfully] plant other seeds that bear the type of mature fruit that we are accustomed to eating.

The land is inhabited by two kinds of people, Moros [Moors] and gentios [heathens]; the latter are natives [of the island], while the former were foreigners who came for reasons of commerce and began to settle and populate the maritime region, multiplying so quickly that in less than 150 years they had established themselves as senhores [lords] and began calling themselves kings. The heathens, leaving the coast, took refuge in the interior of the island and live there today. Those who live in the part of the island facing Malaca ${ }^{25}$ are called Batas [Bataks]. They are the most savage and warlike people in the whole world; they eat human flesh. Those who inhabit the southern part of the island are called Sotumas ${ }^{26}$ and are more couersaueis [tractable]. As with the Moors who live along the coast facing toward Malaca, though the heathens differ from one another in their languages, almost all of them speak Malayo de Malaca [Malaccan Malay] because it is the language most used in the whole region. And

24. According to Marsden, "The large roes of a species of fish (said to be like shad, but more probably of the mullet-kind) taken in great quantities at the mouth of the siak River, are salted and exported from thence to all the Malayan countries, where they are eaten with boiled rice, and esteemed a delicacy." Marsden, History of Sumatra, p. 176.

25. The phrase in Portuguese is "que cay contra Malaca."

26. None of the authors consulted was able to identify this ethnic group. 
all of these people, including those who live in the jungles of the island, have pale skin and straight hair, are well-disposed and good looking; thus they do not resemble the Javanese, who though close neighbors, are very different from these people.

Most of the people of the island [Sumatra] call themselves Iauijs [Djawis] ${ }^{27}$ and among them are certainly found the Senhores [masters] of this great island. But it was first the Chijs [Chinese] who controlled the commerce of [Sumatra] and [between it] and India. Because of this striking difference in facial characteristics, which we already discussed in the case of the people of Iaoa [Java], it seems proven that they [the Djawis] are not natives of the land which they inhabit but people who have come from areas of China, because they resemble the chinese and imitate them in their politeness and their mechanical ingenuity.

Before the Portuguese conquered India, the arms used by the inhabitants of Samatra were frechas de Zaravataras hervadas [poisoned arrows (shot) from blowguns], similar to those the Iaos [Javanese] use; but after we had taken Malaca and, as a result of their warfare with us, they became very ingenious in battle and developed all types of arms, including artillery made from iron and bronze, although most of their cannon came from Portuguese ships which had either been captured or shipwrecked in the area, as we will recount later.

At the time the Portuguese arrived in India, some $29 \mathrm{king}-$ doms were found along the coast of this great island [Sumatra], but since we became involved with these oriental states, favoring some and suppressing others, according to the way they received us, of the 29 kingdoms named below, many have been absorbed into the territory of their most powerful neighbors. Beginning at

27. This particular passage proved difficult to translate because Barros used conflicting terminology. Although Arabs tended to refer to all Muslims from the archipelago as Djawi, it is not entirely certain from Barros' orthography whether he intends to imply the same distinction between Djawi and Javanese. The original Portuguese sentences are offered here with the terms underlined. "E principalmente chamandose per nome comũ toda a gente desta ilha Iauijs: por se ter entrelles por cousa muy certa serem ja os Iaos senhores desta grande ilha, $\varepsilon$ primeiro que os chijs teueram - comercio della $\varepsilon$ da India. E cõ esta variedade tam notavel no aspecto do rostro, parece ficar verificado o que ja dissemos desta gẽte da Iaüa: nam ser natural da terra que habitam, mas gente vinda das partes da China, por imitarẽ os Chijs no parecer $\&$ na policia $\varepsilon$ engenho de toda obra mechanica. . . como os mesmo Iaos usam." 
the western and southernmost point of the island ${ }^{28}$ and proceeding around the coast from the north, the first kingdom is called Daya and those which follow are Lambrij, Achem, Biär, Pedir, Lide, Piradá, Pacem, Bāra, (or Bata), Darú, Arcát, Ircam, Rupāt, Purij, Ciāca, Campār, Capocam, Andraguerij, Jambij, Palimbam, Taná, Malayo, Sacampam, Túlumbauam, Andaloz, Piriaman, Tico, Bárros, Quinchel and Mancopa, which borders on Lambrij, the neighbor of Daya and the first kingdom mentioned above. ${ }^{29}$ The island is very large and in the sertão [jungles] of the interior are many princes and lords about whom we have no special information. Therefore we will deal here only with those kingdoms with which we carry on commerce or warfare.

Although some of [these coastal states] are little more than cities ruled over by men calling themselves kings, others have great power and have cost us much blood, as this narration will prove. Of all these kingdoms, Pedir was the greatest and the most famous in the area, dating from long before Malaca was settled. To [Pedir] came all the ships from the west and the east, as if to a market or emporium where all types of merchandise could be found, for this kingdom was lord of the strait between Samatra and the mainland. But after Malaca was founded, and particularly after the arrival of the Portuguese in India, the Kingdom of Pacem began to grow while Pedir began to diminish. The Kingdom of Achem [Atjeh], its neighbor and once its inferior in power, is [now, c. 1560] the greatest of all, but such is the constant flux [in power] among these states that one must observe them closely. Jorge de Brito was the man who first suggested the great importance this kingdom [Achem] would have someday, as we shall see later.

The kingdom of Pacem, where, as we noted, Jorge de Albuquerque helped put a new prince into power, had a novel

28. Barros clearly means "northernmost" point, although he uses the Portuguese word austral; see, Armando Cortesão, The Suma Oriental of Tomé Pires (London: Hakluyt Society, 1944), Vol. I, P. 135, note.

29. Pires lists these places, divided in his terminology between kingdoms (reinos) and countries (terras), as follows: Reino de Achey e Lambry, Terra de Biar, Reino de Pedir, Terra de Aeilabu, Reino de Lide, Reino de Pirada, Reino de Pacee, Reino de Bata, Reino de Daru, Reino de Arcat, Terra de Yrcan, Reino de Rupat, Terra de Purim, Reino de Ciac, Reino de Campar, Terra de Campocam, Reino de Andarguerij, Terra de Tuncali, Terra de Jamby, Terra de Palimbão, Terra de Tana Malaio, Terra de Çacampom, Terra de Tulimbavam, Reino de Andallos, Reino de Piramã, Reino de Tiquo, Reino de Barus, Reino de Quinchell, Reino de Mancopa or Daya, Reino de Menancabo. See, ibid. 
custom that made it dangerous for one to want to be king because the people granted him only a short time to live. So unfortunate was any heir to the throne that the people gave it to whomever sought it. There was one advantage, however, one granted to few men, and that is to know the hour of his death, or if not the hour, at least the day; but if [the timing] was uncertain, he would not go out all week. When this madness or fury rose up in the people, everyone paraded through the streets chanting a dinge: "The king must die." There was no one to oppose this cry nor anyone whose ears were offended by it, except the king and some of his closest advisors who, as soon as they heard the death chant being sung, gathered around him. Often they perished together. When Fernão Peres d'Andrade stopped over in Pacem to load spices on his way to China, two kings were killed and no one paid the slightest attention, nor was there any commotion or tumult in the city; it was not as if a reigning king had died. The people elevated another whom they had chosen to govern them, having convinced themselves that their custom was a good one because it was ordained by God. For they said that anyone as great as a king, one who governed on earth in the place of God, could not possibly be killed if God did not permit it. If God permitted the king to be killed, then he must be guilty of such sins that he did not deserve to be king and anyone might kill him. Because the murderer was considered of the royal lineage, inasmuch as he had killed a king, he seated himself on the throne and remained there unhindered, being regarded among the people as their legitimate king. At times there are so many revolts in this kingdom that once three kings sat upon the throne in one day, each having been killed by the other. ${ }^{30}$

The Prince whom Jorge de Albuquerque brought there [to Pacem] knew of this cruel custom but he was too young to be afraid, while others with more judgment attempted to control the kingdom. The incident which obliged the prince to go to India to ask for help from the Portuguese occurred as follows: we have already written how Afonso de Albuquerque, while en route to Malaca [in 1511] stopped in Samatra and later captured a junk which the Portuguese called o Bravo [The Brave One] because of the great difficulty that seizing it entailed. Aboard this junk was a prince named Geinal, an heir to the throne of Pacem, who was planning an uprising against his uncle, the governor [or acting ruler] of the kingdom. We have also described how Afonso de Albuquerque, when he learned of his [Geinal's] plight, took him along with him to Malaca, offering him the hope that he would be restored to his throne. But the prince did not want to wait and disappeared when Afonso de Albuquerque was about to return to India, perhaps because he feared that Afonso de Albuquerque would take him to India or for some other reason.

30. Pires describes the same custom, adding the proviso that the throne would only be granted to a Muslim. Ibid., Vol. I, p. 143. 
After the prince fled, he joined the former King [Sultan] of Malaca [defeated by Albuquerque in 1511] who in those days was also in exile. The King of Malaca beguiled [Geinal] with the hope that when [the Sultan's] tasks were completed, he would help [Geinal] recover the kingdom of Pacem. After six or seven years had passed, [during which] the prince married a daughter of the king, they had all gone to live in Bintam ${ }^{31}$ and were resting on their laurels after a series of victories gained at our expense. Then the king ordered that a fleet be raised to assist [the prince], for during that same period, certain things had happened in Pacem: The uncle from whom Prince Geinal had fled, who was the brother of his mother and a former king of the neighboring state of Aru, had made himself the master of both kingdoms. But the people of Pacem, who had the custom we have described, that is, of becoming angry with a king and then seeking his death, wasted no time in dispatching this ruler, since he was a foreigner, and then raised up another who was a native. But the latter did not last long either, because some people from Aru, who were still residing in Pacem, having come there when their king was in power, now worked to kill this nativeborn king. They succeeded in their task and had just replaced him with a new king when Prince Geinal, with the powerful assistance of his father-in-law, the King of Malaca, arrived in Pacem and killed the then-reigning monarch. It was the [murdered] king's son whom Jorge de Albuquerque brought with him to Pacem. This boy, who was about twelve years old, relied upon a Moor, one Moulana, ${ }^{32}$ the supreme caliph of the Moors in that region, and it was he [Moulana] who brought the boy to India to ask the help of Diogo Lopes [the Portuguese viceroy, 1518$1522]$.

Taking account of the fact that Geinal had used the help of the King of Bintam [the former Sultan of Malacca] to seize power in Pacem, and that his father-in-law had done much damage to the Portuguese and was hated by them, it suited the Portuguese that the boy was an orphan and could become a vassal of the King of Portugal. [His argument was that] he was seeking help to fight someone who was an enemy of the Portuguese.

At the time when Geinal arrived in Pacem, there was a Portuguese merchant in the city, one Gaspar Machado, sent by the Captain of Malaca. Fearing the consequences if the son-inlaw of the King of Bintam, our enemy, established himself in Pacem, Gaspar Machado fled to Malaca and in the confusion abandoned much of his property and goods. On learning that a Portuguese had been there and had fled in fear, King Geinal

31. Bintan is an island in the Riau Archipelago, south of Singapore. For another version of Geinal's story, see Marsden, History of Sumatra, Pp. 412-413.

32. Moulana was the Portuguese word for Mullah, a Muslim legal scholar. Dalgado, Glossario Luso-Asiatico, p. 77. 
became very disturbed, for even though he had agreed with the King of Bintam that they would jointly make war on Malaca, which was the reason the king had given him his daughter in marriage, as well as a great deal of help in recovering his kingdom, Geinal's true intention was not to offend but rather to favor the Portuguese, for he feared that their enmity would cost him the kingdom. With this in mind, therefore, he stopped a Portuguese ship which was passing nearby and, after the warmest of welcomes, sent a message to García de Sá, Captain of Malaca, asking that Duarte Coelho be dispatched there immediately to negotiate a peace treaty [between Portugal and Pasai].

[Later], when a commercial treaty was in force between us and peaceful conditions obtained, a Portuguese chanced to arrive at the port [of Pasai], one Diogo Vaz, a man of evil mind and worse conscience, who caused a break in these peaceful relations in the following manner: As noted previously, Diogo Vaz had gone with João Gomes to the Maldivas [Maldive Islands] as captain of a fusta [pinnace] which, after nearly reaching the islands, was driven away by storms and currents and finally made land at Choromandel [Coromandel]. There he took [passage on] a ship loaded with roupa [dry goods] heading for Samatra and Malaca. But being overloaded, and carrying more people than it should have, it foundered in a storm, drowning both passengers and crew. [It did not sink, however,] and Diogo Vaz was rescued by a [passing] junk and taken to Pacem where he was well received by the then-reigning king, Geinal.

It was the custom in these kingdoms that all imported merchandise had to be offered to the king's officials for prices fixed by the king before anything could be sold. These officials took the bulk of Diogo de Vaz' merchandise to the king but Geinal was busy consolidating his rule and, moreover, did not have enough money to pay high prices for what was offered him. He wanted to sell the goods in the kingdom, keep the profit for himself and then pay Diogo Vaz. There would be some delay in this manner of payment which Diogo Vaz was not willing to abide, and, because he was a rebellious man and very impatient, he asked frequently for his money from the king, using words so indiscreet that men close to the king were outraged. The next time that Diogo Vaz used such language in the king's presence, these servants killed him with their crisadas [krises]. And with this, indignation arose among the people of the city and they cried out in one voice, "Kill them, kill them!" And [ in the process] several Portuguese were killed, including some of those with Diogo Vaz and others from the Goan ship owned by the factor Ruy da Costa and then under the command of Captain João de Borba. But since the death of Diogo Vaz was more accidental than planned, as were the deaths of those killed in the streets of the city, João de Borba's ship made no attempt to flee, because there remained much merchandise to collect from the port. This ship was quickly loaded, however, before anything else occurred, and when it reached Goa, the word spread that King 
Geinal had made himself our enemy. Shortly after this, the prince whom Jorge de Albuquerque had brought [from Samatra] came to ask for assistance against Geinal. It was granted to him, as the following chapter will describe.

[In 1514, the Portuguese Viceroy of India sent his cousin, Jorge de Albuquerque, to take charge of the city of Malacca and its fortress, already known widely as $A$ Famosa. The younger Albuquerque was ordered to stop en route at Pasai and to overthrow Sultan Geinal, replacing him with the King of Portugal's new vassal, the Orphan Prince.]

\author{
Decada III, Livro V, Capitulo ii \\ How Jorge de Albuquerque ${ }^{3} 3$ arrived \\ at the kingdom of Pacem, met the \\ tyrant in combat, captured his \\ whole force in the fortress and \\ restored the prince to power.
}

Jorge de Albuquerque was despatched from Cochij with the orders referred to above and was accompanied by many of the captains who normally stopped at the port of Pacem to load or discharge cargo, including Jorge de Brito, ${ }^{34}$ commander of an armada of eight vessels en route to the Molucas. All [the captains] were under the flag of Jorge de Albuquerque, but some preceded the fleet and others followed later, while some ships called at ports before Pacem. When [Albuquerque's] fleet reached Pacem, it found Rafael Perestrello's ship already anchored at the bar, since of the six large ships in the fleet, his had gone farthest ahead, followed by those of Dom Afonso de Meneses, Dom Sancho Alvariquez--his son-in-law who was on his way to take the post of harbor commander at Malaca. Diniz Fernandez and Rafael Catanho arrived after the business to be discussed here had ended. In company with Rafael Perestrello, they also found Manuel da Gamma, whom the Captain of Malaca, García de Să, ${ }^{35}$

33. Jorge de Albuquerque was Captain of Malacca twice, returning to Portugal between 1514 and 1519. During his second tour of duty, in 1524, he defeated the King of Bintan, the exSultan of Malacca.

34. Jorge de Brito was sent to the Moluccas in 1518, but was killed in a battle with the Sultan of Atjeh while en route, as described below.

35. The current Captain of Malacca (1518) was Ruy de Brito. García de sá did not become Captain until 1519, according to Ian MacGregor, "Notes on the Portuguese in Malaya," Journal of the Malayan Branch of the Royal Asiatic Society, 28 (1955), pp. 5-47. 
had sent with an armed caravel to convoy a junk, carrying goods which the merchants of Malaca had sent to exchange with the king, as is the custom among these people.

The Portuguese found a junk there too, one commanded by João Pereira, which had already called at the port of Aru to load grods. It happened that the King of Aru was [already] at war with Pacem, because the present ruler, Geinal, was responsible for the murder of his predecessor. Therefore, [the King of Aru] suggested that he send part of his army aboard the Portuguese ship and that he lead the rest against Pacem by land. João Pereira agreed to this, knowing what Prince Geinal had done to the Portuguese who had accompanied Diogo Vaz. Thus it happened that the King of Aru had already reached [Pasai] the day before Jorge de Albuquerque arrived, but he waited to see what Jorge de Albuquerque would do, knowing that the Orphan Prince had been promised Portugal's support and assuming that this expedition would fulfil the promise. He soon learned that this was true, because Jorge de Albuquerque despatched João Pereira to inform him that the fleet had come in the service of an important vassal of the Portuguese king. Even though the port of Aru was not so well known among the Portuguese as Pacem, the captains of Malaca had received many favors from its king and Jorge de Albuquerque now sent him his thanks for his offer of help, announcing that the fleet had come to overthrow Geinal, an enemy of the Portuguese, and to replace him with the [Orphan] Prince. The messenger added that if the King of Aru had come to wreak vengeance, it would soon be accomplished by Jorge de Albuquerque, whether the king joined [the fight] or stood by to watch. But the king replied that he had brought his army to attack [Pasai] and he asked approval to join in the battle, simply to uphold his own honor and not to seize booty; to that, he renounced any claims for himself and the troops he had brought with him. Permission was conceded to him on these terms, and word of their negotiations was carried [by a messenger] to King Geinal in his fortress. Seeing everything that was arrayed against him, an army on the land and an armada at sea, Geinal knew that the point of the message was to inform him that he would be allowed to surrender his throne by negotiations, but if he chose to fight, he would die, since all were against him, even the people of Pacem, whose king he had kilzed. For if the people paid little attention to the death of a king at their own hands, as we have described, they would all have died defending a king they had raised up or would certainly avenge his murder. ${ }^{36}$ The reason they had not done so thus far was that Geinal, knowing their custom, had established his residence half a league outside the city, where a river rises up out of the earth. There he was not subject to their power and, moreover, was beyond the range of

36. This practice of regicide is also discussed by Pires (Suma Oriental, pp. 143-144) and Marsden (History of Sumatra, pp. 412-413). 
our ships in the harbor. He had built his palace on a high point with a view of the city; it had a wooden palisade around it, like the walls of a town, and was completely surrounded by a moat with only two gates for his servants to come and go. Inside the main palisade, he built another, even stronger, as a sort of castle, within which were his own houses, built also of wood and of reeds from the earth, as is the style there. Inside the castle, he kept his goods and his wives. Around [this inner wall] was built the settlement for his guards who, at the time of Jorge de Albuquerque's arrival, numbered some 3,000 men of the most carefully chosen and loyal that he could find. Nevertheless, because he lacked faith in them, and feared that something might turn them against him, he forced them to live inside the main enclosure, with all their goods and their wives. Finally, because he feared for his life, he never left the fortress.

When Jorge de Albuquerque dropped anchor, Geinal disguised these fears and invited him to come [to the palace] to call. His invitation was carried by a man who acted as if Jorge de Albuquerque need fear no danger; he said, "Your arrival is welcomed here because soon you will go to Malaca as captain and we will be neighbors; therefore, ask for whatever provisions you need for your passage, because [neighbors] must lend things to one another." To this, Jorge de Albuquerque responded that he had no need of anything at the moment except for [Geinal] to give up the throne in favor of the heir whom [Albuquerque] had brought with him, a vassal of the King of Portugal, his lord. He also gave orders [for Geinal] to hand over the goods that belonged to the [murdered] Portuguese and the bodies of those who had been killed, as well as the prisoners who had been taken. Jorge de Albuquerque said he had pressing business in Malaca and could not delay over details; therefore, all the things he ordered should be done immediately so he could communicate to the Governor of India that his mission had been accomplished.

Geinal was very frightened by this reply because he knew very well that all these things would have to be carried out; nonetheless, hoping to reduce the insult, Geinal sent another message, this one via Nina Cunhapam, a heathen who was our friend, and, as the former $x a b$ andar [shahbandar] had ransomed Gaspar da Costa, Antonio Pacheco and the other men who had escaped from Achem, as we discussed earlier. ${ }^{37}$ Because of the friendship between Nina Cunhapam and the Portuguese, [Geinal] hoped he might moderate their resentment. The substance of [Nina Cunhapam's] words was as follows: he knew of no reason

37. The harbor commander of Pacem, Nina Cunhapam, also spelled Nina Chatu, has been cited by other Portuguese authors as a man sympathetic to their cause, largely it seems, because he was not himself a Muslim. 
why a young boy should be the truer heir to the throne than the [incumbent] ruler who, if it were requested, would happily become a vassal of the Portuguese king. Geinal had habitually demonstrated his desire to maintain peace and friendship with the Captain of Malaca, as Nina Cunhapam himself was in a position to know, since he had acted as an intermediary on many occasions when Geinal had dealt with the Portuguese in a friendly fashion and also when he had worked to advance the interests of the King of Portugal. As to the Portuguese goods, he knew nothing about them, except that a man of evil mind and worse language had come and had been killed, for reasons connected with his own party. The goods he brought with him, it was learned, had been stolen from a ship destined for Pacem with cargo for certain local merchants; therefore, after his death, the goods had been given to the merchants who had ordered them, once it had been ascertained to whom they belonged. Even if the other concessions he had already offered were insufficient for Jorge de Albuquerque, Geinal would never give up the throne which had been his father's; to take it from him would mean depriving him of his life, which he would defend.

Other messages came from Geinal later, but none proved acceptable to Jorge de Albuquerque, who had orders to fulfill. And taking counsel with the men who were with him, some 300 against the enemy's 3,000, he decided that he would have to reconnoiter [on land], because without seeing the fortress, he had no idea of its size or location, and could not devise a course of action. Setting out on this route, his party had reached a large tree by late afternoon and here Jorge de Albuquerque decided to rest [overnight]. Nina Cunhapam soon reached him with a message from Geinal asking that he control his anger, because Geinal would make all the concessions demanded and, even now, was conferring with his advisors about how to proceed. Nina Cunhapam took the answer back and soon returned with the news that Geinal was moving his wives and property out into the jungle through a second gate on the far side of the fortress. Nina Cunhapam, realizing that the answer which Geinal had sent to Jorge de Albuquerque was hasty and that Geinal did not really mean to keep his promise, wished to avoid both the wrath of the Portuguese and the hatred of Geinal, so he refused to return again, saying that he had done what he was ordered to do and would carry no more messages. Jorge de Albuquerque told his captains to prepare to spend the night by the big tree, since they had neither ladders nor other equipment to attack the fortress, but only swords, lances and rifles. He warned them to be especially vigilant until morning when they could bring ammunition from the ships and engage Geinal's forces in combat.

Meanwhile, the King of Aru drew near and he awaited word from Jorge de Albuquerque about how he should proceed; several messages were exchanged, but finally Jorge de Albuquerque sent a man to tell the king to stand ready but not to try to enter the fortress until he could see that the Portuguese had forced open 
the gate. Realizing that [the King of Aru's] troops might create disorder by entering the battle, Jorge de Albuquerque asked that they attack from the side [of the fortress] facing the jungle, which they knew better, and to pursue the enemy if he attempted [to flee] by that route. Moreover, he asked that [the king's troops] wear a green branch in their headdress to distinguish themselves from the enemy, lest they be attacked in error by the Portuguese.

While these messages were passing back and forth, the Moors fired several musket shots from their stockade, one of which broke the leg of Francisco Quatrim, a servant of the Count of Portalegre, Dom João da Silva. When the Portuguese realized what had happened they began to complain to Jorge de Albuquerque saying, "Senhor, what are we doing here; why don't you order us to kili them all tonight; why do we wait for ladders when we have our own hands?" And with that, a rumbling began, and the soldiers incited each other to combat. Jorge de Albuquerque, seeing the excitement spreading and realizing that this was the stuff of warfare, decided not to let it pass, but said to his captains, "God has made us their leaders." He ordered the trumpets to sound and cried "In the name of Jesus, Our Savior." It was as if a great wave of water crashed through a barrier that had withheld it, and it lashed out with a force that was unexpected; thus did our troops rush forward crying "Santiago," 38 charging so impetuously that there was no hesitation until they reached the stockade itself. There some tore out stakes from the palisade to force a hole and others knelt for their comrades to climb on their shoulders; two or three men pulled out one stake and succeeded in gaining an entry. None of our soldiers paid any attention to the Moors who were throwing down spears from above and using every kind of weapon to drive them away. Because seafaring men are the most clever at scaling heights, the first man over the top was a calafate [calker] from the nao of Rafael Perestrello, whose nickname was Marquez, and the second was a sailor named Pestana; behind them came a mulatto who was also a man of the sea.

At the same time, Dinis Fernandez de Mello and the men from his ship ran along the side of the wooden barrier until they found a broken post in one corner and, quickly forcing their way inside, were followed by others. Within the wall, they raced toward the gate to open it for the forces outside; but it was already open. This was the main point of attack for our forces, and the principal defensive position of the enemy, so the troops with Jorge de Albuquerque had worked hard to force open the gate and clear the area. [It seemed as if] Our Lord wanted to show them the principle of victory. Above this gate was a kind of sentry box, built in such a way that twenty or thirty men armed

38. A war cry, particularly of Spanish troops, but used also by the Portuguese. St. James the Elder, one of the Twelve Apostles, is the patron saint of Iberia. 
with stones and lances could defend the gate against any attempt from below to force it open. It was this strong point that our scalers had attacked first.

Sultan Geinal had concentrated his defenses at this point and he remained there himself, giving orders and encouragement to his troops. Seeing this figure [on the ramparts] and only remarking his diligence in defending it, without realizing who he was, one of our soldiers, Cide Cerveira, aimed his musket and fired, causing the target to fall like a bird shot through the head by a hunter. With Geinal's death, his men ceased defending the gate; the first man to pass through it was Bartolomeu Cayado, a retainer of the Duque de Bragança, Dom Gemes, and behind him came the whole body of the Portuguese force.

In fact, this was only the outer defense of the large camp within and here the mass of the Moors, like men anxious to die, began to strike out fiercely at our men. Whereupon, Jorge de Albuquerque gathered his soldiers together in one place because, after the attack on the main gate, they had spread out in many directions and once inside the stockade, they threatened to become lost. in the multitude of Moors. Once regrouped, they shouted "Santiago" and rushed forward together down the wide street that lay between the outer defenses and the inner wall of the fortress itself. In the struggle, some of our men were killed, among them, Christovão da Costa, a servant of the Queen, Dona Lianor, and Afonso de Fratos, a native of Alcacere do Sal. One very brave man, Eitor Anrriquez, tried to put a spear through the head of one of the war elephants, but the elephant pushed the lance aside with his trunk, grabbed Eitor Anrriquez by the legs and threw him through the air as if he had been an orange; thanks be to God, he was able to keep his weapons. He landed in a place where he could defend himself and he was not killed. Another elephant was attacked by Domingos de Seixas, who went about it differently, however. Using his lance to bring down the negro ${ }^{39}$ who was directing the elephant from above, he stabbed the elephant, which, maddened by the noise of our guns and the pain of its wound, turned against its own masters, trampling them to death. At the height of battle, the Moors retreated toward the smaller stockade which, as we noted earlier, was inside the main fortress; their conduct suggested that they hoped to regroup near the gate that opened onto the forest.

This [gate] had already been discovered by Afonso de Meneses and the sailors from his nao who had followed the whole perimeter of the stockade earlier in their search for a way to break in, though at the time, they had not understood the function of this

39. In this instance, negro probably refers only to a darkskinned Sumatran; the earlier reference to a mulatto suggests a man from one of Portugal's African colonies, perhaps the Cape Verde Islands, whose population was largely mulatto. 
gate. When the Moors saw them outside trying to find a way in, they realized that they were completely surrounded and that their only salvation lay in battle, because both in front and behind them there was only fighting and death. When the Portuguese outside tried to smash in the gate, the Moors answered them in kind. But the King of Aru had also searched out this same gate, where Dom Afonso and his men were, because he knew that his enemies would try to use it to escape into the jungle. He now brought all his men forward to the aid of Dom Afonso and began finishing off their [mutual] enemies. After the battle was over, the two stockades were covered with more than 2,000 dead men and about 700 others were stretched out upon the ground; it was the most ugly sight imaginable.

of our men, besides those already mentioned, another was killed: Bartolomeu Fernandez, a servant of the Duque de Bragança and a sailor on the nao of Jorge de Albuquerque. Our wounded were: Jorge de Mello, Gaspar da Costa, Jorge Lobo and Jorge de Albuquerque, who had two arrow wounds, one in the face, the other in his body. Because the people of this island are given to using poison, Jorge de Albuquerque ordered that all the wounds be sucked clean before the poison began to work. He sent a message to the King of Aru saying that he intended to take vengeance on their common enemy [Geinal] by handing over the fortress to the [King of Aru] but only on the following day, because it was now too late to move his soldiers back to the ships. On the following day, Jorge de Albuquerque gave the fortress to the people from Aru to sack, and they went about it with great abandon, throwing all the king's goods into great piles and offering many things to Jorge de Albuquerque, both for himself and for his country.

The battle now over, Jorge de Albuquerque turned to the question of the throne; he ordered that an elephant be covered with panels of silk and made ready to carry the boy [the Orphan Prince] into the city. Our troops marched behind, led by their fidalgos [nobles] and by the principal Moors of the city. The boy was conducted through the city with much pomp and the flourish of trumpets. Denouncing the former king, Jorge de Albuquerque installed the boy as his successor, in the name of the King of Portugal, who had invested the prince with the legitimate title and, by force of arms, had ousted the former tyrant, as was the obligation of a lord to his vassal. As soon as the ceremony of formal investiture had concluded, Jorge de Albuquerque convened a second public assembly at which he named the Moor Moulana to be governor and Nina Cunhapam to be xabandar; both of them were known for their good will and their services to the Portuguese when they had served in these same offices during the reign of the boy's father. At the second ceremony, Jorge de Albuquerque said that the new King of Pacem, because he was a vassal of the King of Portugal and had received his throne from the hands of a servant of the King of Portugal, as the result of victory in battle, must therefore pay as a vassal's 
obligation the salaries of all the officers and all the troops of the fortress which would be constructed to safeguard the kingdom. Moreover, all the pepper that the King of Portugal might require must be sold at the price of two cruzados the bahar of four quintals each. ${ }^{40}$ Then Jorge de Albuquerque ordered that the wood from Sultan Geinal's stockade should be used to build a fortress on a favorable site near the mouth of the river, to stand there until a better one could be built of mortar and stone. He left behind, as officers of the fortress, Antonio de Miranda d'Azevedo, whom he ramed to be captain, Antonio Barreto as bailiff, Pero Cerveira as factor, and such other clerks and officers as were common in the [Portuguese] fortresses in India.

Several days after Jorge de Albuquerque's victory, Antonio de Brito arrived with the fleet belonging to his brother, Jorge de Brito, which had lost many men in a disastrous incident in the port of Achem on the same day as Jorge de Albuquerque's victory. This will be described in the following chapter.

Decada III, Livro V, Capitulo iii
How Jorge de Brito and his fleet
reached the port of Achem where
he and some of his captains and
many of his men were killed in
a battle with the king; and how
his brother, Antonio de Brito,
came upon the ships at Pedir and
took command over them; and of
the other things which he
experienced with Jorge de
Albuquerque before they reached
Malaca; and of what happened to
the other captains who were
left behind in Pacem.

Jorge de Brito did not leave Cochij at the same time as Jorge de Albuquerque because his ships could not be fitted out as quickly, but he wasted no time in setting out in his wake, with six navios under the following captains: Christovão Correa, Christovão Pinto, Francisco Godiz, Lourenço Godinho and Pero Fernandez. The last ship was a fusta under its captain, Gaspar Gallo, while the others were all navios, some round [rigged] and others latin [lateen]. One other navio was commanded

40. Cortesão says a bahar was an old measure of weight formerly used in India and the archipelago and usually estimated at 400 lbs. avoirdupois (Suma Oriental, I, p. 82, note 3 ). Marsden writes that a bahar equalled 530 (English) pounds (History of Sumatra, p. 130 ). 
by Jorge de Brito's brother, Antonio, but it could not be made ready in time to sail on the same day and was to rendezvous with the fleet at the port of Achem on the island Samatra. There he was to inherit command of the whole fleet, as a result of what happened to his brother, as we will now see. In addition to the crews of the ships, the fleet carried a complement of soldiers numbering some 300 .

When the five ships reached Achem, which is below Pacem some twenty leagues toward the south, 41 they found one João de Borba, a native of the [Portuguese] city whose name he bore and a speaker of the Arabic language, as well as several other languages of that region, for which he was well known among the Moors. He had fled to Achem from Pacem when Diogo de Vaz was killed there, as we described earlier.

Now because [João de Borba] was so well received in these parts, he had been chosen by certain officials of the [Portuguese] king at Goa to take a ship as far as Mascate [Muscat] and there to load a cargo of moxama, 42 an article which would fetch a good price in Samatra. But a storm in the gulf between the Maldivas and Samatra sent the ship to the bottom. of the crew, fifteen managed to save themselves in a small boat, while nine others went with João de Borba on a raft. The seas were so heavy that the boat could not be steered and it drifted with all the men aboard as far as Pegu. Rafael Perestrello, who was then in Bengalla, heard of their whereabouts from a Moor named Alle Aga. But João de Borba and the nine persons with him [on the raft] drifted along the coast of Samatra for nine days and finally, miraculously, reached the port of Achem. During all this time, moreover, neither he nor the other eight had had anything to eat or drink; they had but one kernel of anfião [opium] the size of a grain of pepper. João de Borba carried that with him because he had seen a Moor use it, for among them it was well known as a cure; our commercial books speak also of anfião. When João de Borba arrived at the port of Achem, since he was an educated man and learned in the languages of the region, he was received warmly by the king, especially after it was learned that he had been lost aboard a nao that had been carrying merchandise to Achem.

As soon as Jorge de Brito arrived, he was visited aboard his ship by João de Borba, accompanied by several messengers of the king, who welcomed him to Achem and offered him refreshments. João de Borba stayed behind [after they left] and, having described his own good fortune, explained many things about the country

41. This seems a clear case of error on Barros' part; Pasai is south of Atjeh in the direction of Malacca.

42. Moxama is dried tuna, or bonita, which the Portuguese loaded in the Maldives and sold for a profit in India and the archipelago. Dalgado, Glossario Luso-Asiatico, p. 75. 
which enlightened Jorge de Brito and caused him to take his subsequent actions. One of the things [João de Borba] told him was that in Achem there was a great heathen temple which was famous for its gold; he said also that the King of Achem had taken all the artillery and cargo from the ship of Gaspar da Costa, brother of Afonso Lopes da Costa, Captain of Malaca, when [the ship] had been lost nearby. The king had also seized the cargo of a bargantim [barkentine] which had gone down off the neighboring kingdom of Daya. The ship had been commanded by Francisco de Sequiera and had been seeking the Isles of Gold of Diogo Pacheco.43 Moreover, when the king had observed a becalmed ship offshore, one belonging to Dom João de Lima and carrying goods from the Maldivas to Malaca, he had sent out launches to seize it, killing six Portuguese but sparing the rest of the crew who were natives of Malabar. After Jorge de Brito had listened carefully to all these things and had inquired about the strength of the king's forces, he decided to seek more information by sending for Diogo Lopez, whom he was taking with him to the Moluccas, where he would remain with Franciso Serrão. [Diogo Lopez] had been aboard Gaspar da Costa's ship when it had been lost [off Atjeh] and he had been captured and the ransomed by Nina Cunhapam, as we wrote earlier. During his captivity, Diogo Lopez had learned the language of this place, just like João de Borba.

Convinced by these two men of the king's crimes, Jorge de Brito decided to depart from his schedule and, through João de Borba, who was the more accomplished linguist, he sent word to the king that although en route to Malaca, he had been ordered by the Governor of India to stop at Achem and retrieve all the artillery and merchandise which had been taken from the nao and the bargantim which had gone down near there. The king answered that he knew of no more certain place to find these goods than at the bottom of the sea, where the two ships lay now, according to what he had heard; he was not sure, therefore, why this requirement was being made of him. If there were anything else which [de Brito] needed from his kingdom, he would be happy to grant it, since he had always proven himself generous in welcoming any Portuguese who came to Achem, as João de Borba could himself testify.

While these and other messages were being exchanged, one Rafael Catanho came aboard [de Brito's] ship; he had fallen overboard from Jorge de Albuquerque's ship when it passed near [Atjeh], and he asked permission to stay. But Jorge de Brito refused, since all the men were filled with dreams of the gold at the

43. Diogo Pacheco returned to India from Malacca with tales of a fabulous archipelago, the Isles of Gold, said to lie about 100 leagues south of Sumatra. In 1518, Diogo Lopes de Sequiera, third Viceroy of India, provided Diogo Pacheco with a fleet and sent him to search for the isles. Barros refers to this voyage in Decada III, Livro III, Capitulo iii. 
temple and did not want to share it with anyone else. And thus the only ones who escaped from what followed [were this man and another described below]. Or perhaps God did not want to take Rafael Catanho because he was a cavalheiro [gentleman or knight], though others of that rank were taken. Seeing that he was not wanted there because he was not of their fleet, [Rafael Catanho] journeyed down the coastline toward Pacem and, in the port of Pedir, found Christovåo de Mendoça, who had also been present when the subject of the gold at the temple had been raised but who knew how uncertain and dangerous [the attempt to take] it would be. Both of these men joined Jorge de Albuquerque at Pacem, where he was building a wooden fortress, as we described before.

Jorge de Brito, after listening to the tales of that schemer João de Borba, woven together on a loom of death, was full of indignation against the barbarian and took counsel with his captains about how to attack the city. Because his ships' anchorage was about a league down the river [from the city], he ordered that only launches be used at first and that the fusta of Gaspar Gallo, the largest of the small craft, follow later with all the musketeers, the crossbowmen and some light artillery. After the men went ashore from the launches, the fusta would act as a bulwark along the waterfront, ensuring that no enemy troops counterattacked as the Portuguese reembarked.

After giving these orders, Jorge de Brito and his men departed just before dawn. Halfway to their destination, they came upon a small settlement on a spit of land projecting into the water; in its center was a high bluff with a wooden fortification from which a few small cannon commanded the channel. Although it was now broad daylight, Jorge de Brito delayed his attack, waiting for the fusta of Gaspar Gallo, which did not appear. The delay was due to the long time required to load the men and artillery aboard and, even worse, the wind was now blowing from the landward side and down the main channel of the river. But those in the fortification, seeing the boats stopped in the water below them, thought that the Portuguese were afraid to pass because of the cannons. To give evidence of their range and to frighten the Portuguese, the defenders fired several shots. But our troops, hearing these, became excited and began urging Jorge de Brito to order an attack immediately, without waiting for Gaspar Gallo's fusta. They said, "Let us attack now and take them before the cannon begin to kill us off," and, "In order to pass the headland, the cannons will have to be silenced in any case." The men began to importune Jorge de Brito, and he, though still not seeing the fusta, nonetheless, ordered several of the small boats loaded with musketeers to surround the point of land and prepare to cover the other soldiers when they returned from attacking the fort.

With this shield around one vulnerable point, he committed the main body of his forces where the danger turned out to be 
greatest; not because the place itself was hazardous, but largely due to one man's folly, a man named João Serrão. The Portuguese soldiers quickly overran the fort, drove out the Moors and took possession of the three or four cannons. Jorge de Brito was determined to hold this position until Gaspar Gallo and Laurenço Godinho joined them for the assault [on the temple]. Meanwhile, however, the Moors who had been driven off the high ground near the fort had regrouped and mingled with the others from the settlement below. It was then that João Serrão, or Pero de Buião as he wascalled, because he was the aquião [standard bearer], whose head was full of fumes from the wine the troops had received at daybreak to give them courage, led a charge down the hillside and, paying no attention and not stopping until he was in the midst of the Moors, was quickly killed by them. Just behind him came Aires Botelho, who had followed blindly. Others rushed to join them, having seen the standard of Jorge de Brito going ahead, and a fierce battle began, which Jorge de Brito was now forced to join. He left the fort and took the rest of his men into combat with him.

At this moment, the king arrived with between 800 and 1,000 men and six war elephants of the type seen here. But the first danger our men faced was from a herd of bufaros bravos [wild buffalo] which were kept in an enclosure nearby and which now, together with the elephants, threatened to do them great harm. Gaspar Fernandez tried to wound one of the elephants with the point of his lance, but the beast grabbed him with its trunk and threw him high in the air. When he landed, with his weapon still in his hand, he began again to kill the Moors. Jonge de Brito, seeing the damage that the wild animals were doing, sent a messenger in great haste to tell Laurenço Godinho to come forward with his musketeers and crossbowmen and to bring down these beasts which threatened his men.

Then Jorge de Erito moved back uphill to the fort, where he hoped to make a stand. However, so many Moors were already on the ramparts of the fort, throwing down burning sticks, spears and arrows, that they could not be overcome without armor or shields. But some of our men attacked them anyway and when Jorge de Brito went to their aid, he was wounded in the jaw by a spear thrown down from the parapet. Several of his captains were nearby, and seeing how badly he was wounded, begged him to order them to break off the engagement because neither Laurenço Godinho nor Gaspar Gallo had yet appeared. But though he could hardly speak, he answered like the cavalheiro he was, saying that their honor was at stake and that God would be with them. Then he cried, "March forwand, senhores." Almost immediately, he was struck down by a burning torch and, already badly wounded, he soon died. In this, the most intense part of the battle, many others besides Jorge de Brito were killed: Christovão Correa, Christovão Pinto, João Pereira, Francisco Godiz and others; among the latter were three or four musicians whom Jorge de Brito, being fond of music, had allowed to accompany him on this voyage. Seeking novelty, 
they had asked leave to come along that day. Among them was a choirboy from the chapel of King Manuel, one Gomez, about whom it would be difficult to decide which was his most noteworthy characteristic, the excellent quality of his voice or the vices to which he was inclined.

All of our men would surely have perished there if Laurenço Goditho and Gaspar Gallo had not arrived and, using their marksmen to create a beachhead, they took aboard 120 survivors of the force that had been with Jorge de Brito. Of the 200 men who had left the ships with their two captains, more than 50 of the most noble fidalgos and cavalheiros had been killed, and others died of their wounds later. When the remnants had returned to the ships, the only thing they could do was to raise sail and begin the trip down the coast toward Pacem, where they knew they would find Jorge de Albuquerque with the prince he was escorting.

Reaching the port of Pedir, [the survivors of the Atjeh defeat] found Rafael Catanho and Christovão do Mendoça, with three of the ships from [Diogo Pacheco's expedition] to discover the Isles of Gold. When [these commanders] saw [de Brito's] fleet, defeated and without a captain, they wanted to take control of it. But there remained aboard [the decimated fleet] a few men of faith and reliability, and they did not consent because they were awaiting the amrival of Antonio de Brito, Jorge's brother, whose ship had remained behind [in India] for repairs but was due to join the fleet. When Antonio de Brito arrived, the [controversy] ended because among the papers given Jorge de Brito was one signed by King Manuel which provided for Antonio to succeed his brother as commander in the event of the latter's death. Upon assuming command, [Antonio de Brito] realized that the first thing he must do was fill the captaincies and other offices left vacant by the men who had died. He named Symao d'Abreu to be capitäo mayor de mar [second in command], gave the ship captaincies to Pero Botelho, brother of Laurenço Godinho, and Francisco de Brito, and named Ruy Gago as factor and Gaspar Rodriguez as almoxarife [storekeeper]. In the same way, he filled the other positions left vacant by death.

The fleet proceeded to Pacem, where it encountered Jorge de Albuquerque, who by then had promised all these posts to others, and had assigned the command of the whole fleet to Dom Sancho, because according to royal regulations, he [as Captain of Malacca] had jurisdiction over all offices falling vacant in the vicinity of Malaca and could name successors until a man came from Portugal with the king's own nomination. There were reasons on both sides for conflicting understandings on the part of Jorge de Albuquerque and Antonio de Brito, but nevertheless, Antonio de Brito continued to be commander of the fleet. Because he had several things which he wanted to attend to in Malaca before continuing his voyage [to the Moluccas], Antonio de Brito left Pacem ahead of Jorge de Albuquerque, who was still constructing the fortress at the entrance to the harbor. But the 
latter did not delay any longer, even though the fortress would not be finished for some time; he set out for Malaca several days later, leaving Rafael Catanho, Rafael Perestrello and Christovão de Mendoça behind to complete the work and to load the cargo of pepper. Since it was not the season of the monsoon, which determines the direction in which one sails, and Christovão de Mendoca in particular had already missed the time for sailing [to India], all the men were ondered to stay behind and finish building the fort until it could be defended [by its garrison].

Having given these orders, Jorge de Albuquerque sailed for Malaca and arrived there safely to find Antonio de Brito and García de Sá, who handed over the captaincy of Malaca to him.

The truth is that if these captains had not been in favor of [building] the fortress at Pacem, it would not have remained standing very long but, even so, it was preferable to a later and much more expensive fortress which cost us a great deal of suffering $_{i 4}$ Jorge de Albuquerque had barely left Pacem when Milique Ladil, 44 a Moor who claimed title to the kingdom, sailed down a river which flows through the forest and joins another that passes through the center of the city. His army attacked from their launches--oar-driven ships much used in the region of Malaca. They did a great deal of damage to the city and caused casualties among our men. But, worst of all, they stopped supplies from coming down the river, the way foodstuffs normally reach the city, by using thirteen launches to block the channel. Not content with this, however, they came at night to attack the fortress and tried to set it afire, afterward taking shelter in a small strait. Shocked by their boldness, our captains took up arms and led the men out in pursuit. As soon as the Moors felt the brunt of the Portuguese attack, they abandoned their launches and fled through the underbrush. Having defeated their enemies, the captains seized the launches for the use of the fortress.

When the fortress was ready to defend itself, Christovão de Mendoça and Diniz Fernandez left for Malaca. Pero Laurenço de Mello, who had loaded a cargo of pepper for Bengalla, called at Malaca en route but thereafter became lost in the islands which are called Andramú, "5 whose inhabitants are cannibals. And Rafael Perestrello, who was also bound for Bengalla, also ran the risk of becoming lost in the islands, but he arrived safely, for reasons we shall discuss later.

44. Maliku'ladil is Arabic for "the just king"; cf. Ratu Adil in Javanese.

45. Andramú appears to be a misspelling of Andaman, a group of islands which, together with the Nicobars, lie between Sumatra and Bengal and whose inhabitants were often described as cannibals. 